\title{
ANALISIS RANTAI NILAI MINYAK KELAPA (CCO, CRUDE COCONUT OIL) DI KECAMATAN SINONSAYANG KABUPATEN MINAHASA SELATAN
}

\author{
Helena Kelyombar \\ Nordy F. L. Waney \\ Tommy F. Lolowang
}

\begin{abstract}
The purpose of this study was to determine the Coconut Oil Product Value Chain (CCO) in Sinonsayang District, South Minahasa Regency. Analysis of the coconut oil product value chain (CCO), there are several actors involved in the core process of the coconut oil product value chain (CCO) in Sinonsayang District and form a chain that has value. The actors involved included copra farmers, intermediary traders and PT. Cargill. The study lasted for 3 (three) months starting from June 2018 to August 2018 in Sinonsayang District, South Minahasa Regency. The data used are primary data obtained through interviews with 15 copra farmers, 5 brokers and PT. Cargill as a coconut oil (CCO) company. Secondary data was obtained from the Sinonsayang Sub-District Office and agencies related to research. The analysis used is using quantitative tools through cost and margin approaches. The results showed that the copra produced by farmers was 5,041 $\mathrm{kg}$ with a raw material of 20,165 coconuts. With the selling price of copra amounting to Rp.7,500 / $\mathrm{kg}$ and the value received by farmers is Rp.37,809,375. The trader buys copra raw material from the farmer as much as 5,041 $\mathrm{kg}$ then sells to the company as much as 5,083 $\mathrm{kg}$ at the price of $8,500 / \mathrm{kg}$ and the value received by the trader is Rp.42,832,000. The company buys copra raw material from the trader as much as 5,083 kg. From copra raw material, the company produces crude coconut oil (CCO) of 3,527 $\mathrm{kg}$ and 1,007 Kg cake then exports the CCO at a price of Rp. 23,000/ kg and offers a price of Rp. 3,000 / kg value of $R p .84,134,600$. Each value chain actor obtains a margin that is in accordance with the effort made. *jnkd*.
\end{abstract}

Keywords: product value chain, coconut oil (CCO), Sinonsayang District, South Minahasa Regency.

\begin{abstract}
ABSTRAK
Tujuan dari penelitian ini untuk mengetahui Rantai Nilai Produk Minyak Kelapa (CCO) di Kecamatan Sinonsayang, Kabupaten Minahasa Selatan. Analisis rantai nilai produk minyak kelapa (CCO), terdapat beberapa pelaku yang terlibat dalam proses inti rantai nilai produk minyak kelapa (CCO) di Kecamatan Sinonsayang dan membentuk sebuah rantai yang memiliki nilai. Pelaku yang terlibat diantaranya adalah petani kopra, pedagang perantara dan PT. Cargill. Penelitian berlangsung selama 3 (tiga) bulan mulai dari Bulan Juni 2018 sampai Bulan Agustus 2018 di Kecamatan Sinonsayang Kabupaten Minahasa Selatan. Data yang digunakan yaitu data primer yang diperoleh melalui wawancara kepada petani kopra yang berjumlah 15 orang, pedagang perantara berjumlah 5 orang dan PT. Cargill sebagai perusahaan minyak kelapa (CCO). Data sekunder diperoleh dari Kantor Camat Sinonsayang dan instansi-instansi yang terkait dengan penelitian. Analisis yang digunakan yaitu menggunakan alat kuantitatif melalui pendekatan biaya dan margin. Hasil penelitian menunjukkan bahwa kopra yang diproduksi petani sebanyak $5.041 \mathrm{~kg}$ dengan bahan baku 20.165 buah kelapa. Dengan harga jual kopra sebesar Rp.7.500/kg dan nilai yang diterima oleh petani sebesar Rp.37.809.375. Pedagang membeli bahan baku kopra dari petani sebanyak 5.041 $\mathrm{kg}$ kemudian menjual kepada perusahaan sebanyak $5.083 \mathrm{~kg}$ dengan harga $8.500 / \mathrm{kg}$ dan nilai yang diterima oleh pedagang sebesar Rp.42.832.000 Perusahaan membeli bahan baku kopra dari pedagang sebanyak $5.083 \mathrm{~kg}$. Dari bahan baku kopra, perusahan meproduksi minyak kelapa mentah (CCO) sebanyak $3.527 \mathrm{~kg}$ dan bungkil $1.007 \mathrm{Kg}$ kemudian mengekspor CCO dengan harga Rp.23.000/kg dan bungkil dengan harga Rp.3.000/Kg nilai yang diterima oleh perusahaan sebesar Rp.84.134.600. Masing-masing pelaku rantai nilai memperoleh margin yang sesuai dengan usaha yang dilakukan. *jnkd*
\end{abstract}

Kata kunci: rantai nilai produk, minyak kelapa (CCO), Kecamatan Sinonsayang, Kabupaten Minahasa Selatan. 


\section{PENDAHULUAN}

\section{Latar Belakang}

Peranan sektor pertanian sangat penting karena sektor ini mampu menyediakan lapangan pekerjaan, memasok pangan dan menyumbangkan devisa. Pembangunan pertanian pada hakekatnya bertujuan untuk meningkatkan kesejahteraan atau taraf hidup petani, oleh karena itu pembangunan pertanian selalu diarahkan pada produktifitas usahatani dan pendapatan petani. Petani dalam meningkatkan pendapatannya selalu diperhadapkan pada pengambilan keputusan dan merupakan kegiatan terpenting didalam pengelolahan usahatani.

Proses produksi kopra dari panen hingga dikonsumsi konsumen merupakan hal yang penting untuk pelaku karena memberikan keuntungan dan nilai tambah bagi para pelaku. Saluran distribusi adalah sekelompok perusahaan atau perseorangan yang memiliki hak pemilikan atas produk atau membantu memindahkan hak pemilikan produk atau jasa ketika akan dipindahkan dari produsen ke konsumen (Yokebet, 2015).

Produk utama yang dihasilkan dari pengolahan daging buah kelapa atau kopra adalah minyak kelapa (Palungkun, 2001). Minyak kelapa diproses dari daging buah kelapa yang dikeringkan atau dari perasan santannya. Komposisi kimia daging buah kelapa terdiri dari : air 46\%, lemak 34,7\%, protein $3,4 \%$ dan karbohidrat $14,0 \%$. Indonesia mengekspor minyak kelapa ke Negara-negara importer dalam bentuk barang setenga jadi sebagai bahan baku barang turunan lain yang bernilai tinggi.

Sulawesi Utara memiliki luas areal tanaman kelapa seluas 216.132.58 Hektar. Produksi tanaman kelapa di Sulut sebesar 264.607,92 ton per tahun (BPS Sulut 2016). Kabupaten Minahasa Selatan, khususnya Kecamatan Sinonsayang merupakan salah satu wilayah yang memiliki perkebunan kelapa seluas 245,098 hektar. Kecematan Sinonsayang meliputi 13 (tiga belas) Desa dengan komoditi sumber penghasilan utama sebagain besar penduduk adalah kelapa dan kemudian diproduksi menjadi kopra. Jumlah penduduk dan luas wilayah di kecamatan Sinonsayang berdasarkan masing-masing Desa dapat dilihat pada Tabel 1.

\begin{tabular}{|c|c|c|c|c|c|}
\hline \multirow{2}{*}{ No. } & \multirow{2}{*}{ Desa } & \multicolumn{3}{|c|}{ Penduduk (Jiwa) } & \multirow{2}{*}{$\begin{array}{l}\text { Luas Wilayah } \\
\left(\mathrm{Km}^{2}\right)\end{array}$} \\
\hline & & Laki-laki & Perempuan & Jumlah & \\
\hline 1 & Durian & 607 & 566 & 1,173 & 10,80 \\
\hline 2 & Poigar II & 582 & 650 & 1,232 & 22.68 \\
\hline 3 & Poigar I & 729 & 741 & 1,470 & 21.12 \\
\hline 4 & Tanamon & 1067 & 946 & 2,013 & 4.39 \\
\hline 5 & Tanamon Utara & 725 & 651 & 1,376 & 3.25 \\
\hline 6 & Aergale & 454 & 425 & 879 & 10.25 \\
\hline 7 & Ongkaw I & 544 & 531 & 1,075 & 9.05 \\
\hline 8 & Ongkaw II & 1084 & 1041 & 2,123 & 6.80 \\
\hline 9 & Ongkaw III & 444 & 425 & 869 & 14.80 \\
\hline 10 & Tiniawangko & 635 & 587 & 1,222 & 6.24 \\
\hline 11 & BoyongPante & 567 & 545 & 1,112 & 0.54 \\
\hline 12 & Boyong Pante II & 556 & 474 & 1,030 & 0.75 \\
\hline \multirow[t]{2}{*}{13} & Blongko & 879 & 785 & 1,664 & 10.00 \\
\hline & Total & 8,871 & 8,367 & 17,238 & 130.67 \\
\hline
\end{tabular}

Saluran pemasaran dari produsen sampai ke konsumen sangat panjang dan melibatkan banyak pihak yang mengambil margin usaha yang lebih besar dibandingkan dengan pihak lain. Maka untuk melihat nilai dari produk minyak kelapa (CCO) adalah dengan cara melihat rantai nilai kopra sampai pada minyak kelapa (CCO) melalui pendekatan biaya dan margin.

\section{Rumusan Masalah}

Berdasarkan latar belakang, yang menjadi rumusan masalah dalam penelitian ini yaitu berapa besar Nilai Produk Minyak Kelapa (CCO) berdasarkan Rantai Nilai Produk di Kecamatan Sinonsayang Kabupaten Minahasa Selatan.

\section{Tujuan Penelitian}

Tujuan dari penelitian ini yaitu menganalisis Rantai Nilai Produk Minyak Kelapa (CCO) berdasarkan Rantai Nilai Produk di Kecamatan Sinonsayang Kabupaten Minahasa Selatan.

\section{Manfaat Penelitian}

Manfaat penelitian ini yaitu untuk menambah pengetahuan bagi penulis, dan diharapkan dapat memberikan informasi kepada perusahaan dan masyarakat, tentang seperti apa rantai nilai kopra dan juga diharapkan dapat menjadi bahan referensi untuk penelitian selanjutnya, khususnya yang mengambil tema "Rantai Nilai Produk Minyak Kelapa (CCO)". 


\section{METODE PENELITIAN}

Waktu dan Tempat Penelitian

Penelitian ini dilakukan di Kecamatan Sinonsayang dan PT. Cargill yang berlokasi di J1. Raya Trans Sulawesi Kecamatan Amurang Kabupaten Minahasa Selatan. Penelitian ini berlangsung selama 3 bulan dengan waktu penelitian dari bulan Juni sampai Agustus 2018 dimulai dari pengumpulan data sampai dengan penyusunan laporan hasil penelitian.

\section{Metode Pengambilan Sampel}

Metode yang digunakan dalam pengambilan sampel adalah secara Purposive Sampling yaitu sampel diambil secara sengaja. Yang menjadi populasi adalah petani kelapa di Kecamatan Sinonsayang. Sampel yang diambil adalah sebanyak 20 responden yaitu 15 petani kopra, 5 pedagang perantara dan PT. Cargill sebagai Perusahaan Local yang memproduksi minyak kelapa mentah. Hal tersebut dikarenakan informasi responden tidak banyak berbeda dengan lainnya.

\section{Metode Pengumpulan Data}

Jenis dan sumber data yang digunakan dalam penelitian ini adalah Data Primer dan data sekunder. Data primer diperoleh melalui wawancara dengan menggunakan kuesioner yang berisikan pertanyaan-pertanyaan secara tertulis pada responden untuk mendapatkan jawaban, tanggapan, dan informasi yang diperlukan. Data sekunder diperoleh dari instansi atau lembaga terkait dengan penelitian ini.

\section{Konsep dan Pengukuran Variabel}

A. Identitas Responden

1. Umur, ditanyakan dengan satuan tahun

2. Jumlah tanggungan keluarga, ditanyakan dalam orang

3. Tingkat pendidikan, diukur menurut tingkatan pendidikan yang ditamatkan

4. Pengalaman kerja petani, ditanyakan dengan satuan tahun

5. Jumlah pohon kelapa yang berproduksi

6. Luas lahan, yaitu luas lahan yang ditami kelapa (Ha)
7. Status dan kepemilikan lahan, adalah milik sendiri atau sewa

B. Variabel Pokok

1. Petani Kopra

- Biaya produksi yaitu biaya yang dikeluarkan petani selama proses produksi kopra selama satu kali panen $(\mathrm{Rp} / \mathrm{Kg})$

- Jumlah produksi kopra dalam satu kali panen $(\mathrm{Kg})$

- Harga jual, yaitu harga yang berlaku di tingkat petani kopra $(\mathrm{Rp} / \mathrm{kg})$

2. Pedagang Perantara kopra

- Harga beli kopra $(\mathrm{Rp} / \mathrm{Kg})$

- Biaya adalah besarnya biaya yang dikeluarkan dalam proses pengangkutan dan Tenaga Kerja (Rp)

- Harga jual kopra (Rp/Kg)

3. Perusahaan (PT. Cargill)

- Harga beli kopra (Rp/Kg)

- Produksi kopra adalah jumlah produksi dihitung dalam satu kali produksi $(\mathrm{Kg})$

- Proses produksi adalah aktivitas yang dilakukan dalam penerimaan bahan baku sampai penjualan produk

- Tenaga kerja adalah jumlah tenaga kerja yang digunakan dalam 1 kali proses produksi (HOK)

- Biaya adalah besar biaya yang dikeluarkan (Rp)

\section{Metode Analisis Data}

Data yang dikumpulkan akan dianalisis dengan analisis rantai nilai menggunakan alat kuantitatif melalui pendekatan Biaya dan Margin (ACIAR, 2012).

\section{HASIL DAN PEMBAHASAN}

\section{Deskripsi Umum Lokasi Penelitian}

Kecamatan Sinonsayang adalah salah satu Kecamatan di Kabupaten Minahasa Selatan, berjarak sekitar $120 \mathrm{~km}$ dari Kota Manado, ibukota Propinsi Sulawesi Utara. Kecamatan Sinonsayang memiliki topografi wilaya hamparan dengan ketinggian 15 meter dari permukaan laut. Dengan batas-batasnya adalah sebagai berikut : 
a. Sebelah Utara dengan Laut Sulawesi

b. Sebelah Timur dengan Kecamatan Tenga

c. Sebelah Selatan dengan Kecamatan Motoling

d. Sebelah Barar dengan Kabupaten Bolaang Mongondow

Kecamatan Sinonsayang memiliki Luas Wilayah 13.066,7 Ha, dengan Desa terluas Desa Poigar II (2.268 Ha) dan Desa dengan luas Wilayah terkecil adalah Desa Boyong Pante (54 Ha).

\section{Karakteristik Responden}

\section{Umur Responden}

Umur akan mempengaruhi produktifitas dalam bekerja dalam proses pengambilan keputusan diberbagai pekerjaan yang dilakukan. Menurut hasil penelitian, umur responden dapat dilihat pada Tabel 2 .

\begin{tabular}{lccccc}
\multicolumn{7}{l}{ Tabel 2. Jumlah Responden Menurut Umur } \\
\hline \multirow{2}{*}{ No. } & \multirow{2}{*}{ Umur (Tahun) } & \multicolumn{2}{l}{ Jumlah Responden (Orang) } & \multicolumn{2}{c}{ Persentase (\%) } \\
\cline { 3 - 6 } & & Petani & Pedagang & Petani & Pedagang \\
\hline 1 & $32-36$ & 2 & - & 13 & - \\
2 & $37-41$ & 1 & 1 & 6 & 20 \\
3 & $42-46$ & 2 & 2 & 13 & 40 \\
4 & $47-51$ & 6 & 2 & 40 & 40 \\
5 & $52-56$ & 2 & - & 13 & - \\
6 & $57-61$ & - & - & - & - \\
7 & $62-66$ & 2 & - & 13 & - \\
\hline \multicolumn{7}{c}{ Jumlah } & 15 & 5 & 100 & 100 \\
\hline
\end{tabular}

Sumber : Data primer diolah, 2018

Tabel 2 menunjukkan bahwa sebagian besar responden petani kopra paling tinggi berumur 47-51 taahun sebanyak 6 responden dengan presentase 40 persen Untuk pedagang paling tinggi berumur 42-46 tahun sama dengan yang berumur 47-51 tahun sebanyak 2 rensponden dengan presentase masing-masing 40 persen Jumlah ini menunjukkan bahwa sebagian besar responden baik petani maupun pedagang berada pada tingkat yang sangat perpengalaman dalam menjalankan usaha dan pengambilan keputusan.

\section{Tingkat Pendidikan}

Pendidikan petani dan pedagang merupakan faktor yang mempengaruhi pengembangan usaha kopra, dalam hal ini, pendidikan juga dapat mempengaruhi keputusan produksi.

\begin{tabular}{|c|c|c|c|c|c|}
\hline \multirow[t]{2}{*}{ No. } & \multirow[t]{2}{*}{ Tingkat Pendidikan } & \multicolumn{2}{|c|}{$\begin{array}{c}\text { Jumlah Responden } \\
\text { (Orang) }\end{array}$} & \multicolumn{2}{|c|}{ Persentase (\%) } \\
\hline & & Petani & Pedagang & Petani & Pedagang \\
\hline 1 & SD & 6 & - & 40 & - \\
\hline 2 & SMP & 2 & 2 & 13 & 40 \\
\hline 3 & SMA & 7 & 2 & 46 & 40 \\
\hline \multirow[t]{2}{*}{4} & $\mathrm{~S} 1$ & - & 1 & - & 20 \\
\hline & Jumlah & 15 & 5 & 100 & 100 \\
\hline
\end{tabular}

Tabel 3 menunjukkan tingkat pendidikan petani dimana responden terbanyak adalah SMA sebanyak 7 responden dengan presentase 47 persen. Tingkat pendidikan pedagang untuk SMP 2 responden sama dengan SMA, dengan presentase masing-masing 40 persen. Tingkat pendidikan petani dan pedagang sangat bervariasi.

\section{Lamanya Berusaha}

Cara berusaha seseorang sebagian besar dipengaruhi oleh lamanya menjalankan suatu usaha. Semakin lama melakukan usaha tersebut semakin dalam pengetahuan serta semakin luas wawasan seseorang. Tabel 4 menunjukan jumlah responden menurut lamanya pengalaman kerja.

\begin{tabular}{|c|c|c|c|c|c|}
\hline \multirow{2}{*}{ No. } & \multirow{2}{*}{$\begin{array}{c}\text { Lamanya Berusaha } \\
\text { (Tahun) }\end{array}$} & \multicolumn{2}{|c|}{ Jumlah Responden (Orang) } & \multicolumn{2}{|c|}{ Persentase (\%) } \\
\hline & & Petani & Pedagang & Petani & Pedagang \\
\hline 1 & $5-10$ & 5 & 1 & 33 & 20 \\
\hline 2 & $11-20$ & 6 & 1 & 40 & 20 \\
\hline 3 & $21-30$ & 2 & 3 & 13 & 60 \\
\hline 4 & $31-40$ & 2 & - & 13 & - \\
\hline \multicolumn{2}{|r|}{ Jumlah } & 15 & 5 & 100 & 100 \\
\hline
\end{tabular}

Tabel 4 menujukkan tingkat lamanya berusaha responden petani kopra, berusaha 11-20 tahun sebanyak 6 responden dengan presentase 40 persen. Dan untuk pedagang lamanya berusaha 510 tahun dan 11-20 tahun sebanyak 1 responden dengan presentase 20 persen.

\section{Luas Lahan}

Secara umum luas lahan sangat mempengaruhi jumlah produksi yang akan dihasilkan. Menurut hasil penelitian luas lahan responden petani dapat dilihat pada Tabel 5.

\begin{tabular}{|c|c|c|c|c|c|}
\hline \multirow{2}{*}{ No. } & \multirow{2}{*}{ Luas Lahan $(\mathrm{Ha})$} & \multicolumn{2}{|c|}{ Jumlah Responden (Orang) } & \multicolumn{2}{|c|}{ Persentase (\%) } \\
\hline & & Petani & Pedagang & Petani & Pedagang \\
\hline 1 & $1-5$ & 4 & - & 26 & - \\
\hline 2 & $6-10$ & 6 & - & 40 & - \\
\hline \multirow[t]{2}{*}{3} & $11-20$ & 5 & - & 33 & - \\
\hline & Jumlah & 15 & & 100 & \\
\hline
\end{tabular}


Tabel 5 menunjukkan bahwa lahan yang digunakan untuk perkebunan kelapa oleh responden petani kopra paling luas 6-10 Ha sebanyak 6 responden dengan presentase 40 persen Untuk ukuran perkebunan luas lahanyang digunakan responden petani kopra terhitung cukup besar. Dan untuk pedagang tidak ada ukuran lahan perkebunan kelapa.

\section{Identifikasi Pelaku dan Proses Utama Pelaku Rantai Nilai}

Menurut Kaplinsky dan Morris (2001) dalam ACIAR (2012), analisis rantai nilai secara sistematis memetakan para pelaku yang berpartisipasi dalam produksi, distribusi, pemasaran, dan penjualan suatu produk atau berbagai produk tertentu. Pelaku yang terlibat dalam rantai nilai minyak kelapa (CCO) adalah petani kopra ke pedagang kemudian PT. Cargill. Adapun pemetaan proses inti pada rantai nilai kopra menunjukkan proses utama oleh petani yang dimulai setelah pasca panen.

\section{Proses Utama Pengolahan Kopra di Tingkat Petani}

Petani di Kecamatan Sinonsayang hamper sebagian besar memproduksi kopra. Petani juga merupakan produsen utama bahan baku pembuatan minyak kelapa mentah (CCO) pada PT. Cargill. Terdapat berbagai kegiatan yang dilakukan petani kelapa untuk menghasilkan nilai dari kopra dapat dilihat pada Gambar 1.

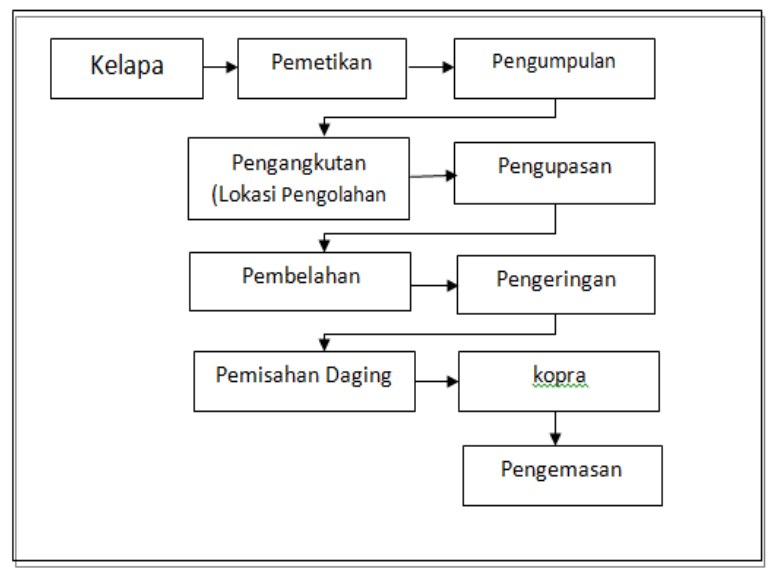

Gambar 1 : Proses Utama Pengolahan Kopra di Tingkat Petani

\section{Proses Kegiatan Pemasaran Kopra di Tingkat Pedagang Perantara}

Setelah menerima bahan baku kopra dari petani ada beberapa kegiatan yang dilakukan pedagang sebelum melakukan penjualan pada peruahaan. Berbagai kegiatan yang dilakukan pedagang perantara untuk menghasilkan nilai. Dapat dilihat pada Gambar 2.

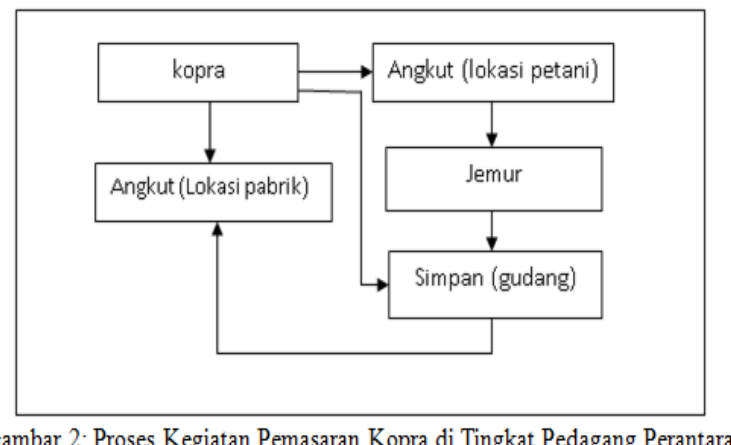

\section{Proses Pengolahan Minyak Kelapa Mentah (CCO) di Tingkat Perusahaan \\ PT. Cargill Indonesia Amurang} bergerak di bidang produk minyak kelapa mentah CCO (Crude Coconut Oil). Minyak mentah yang belum diolah biasanya dieksport ke luar negeri dengan menggunakan kapal laut. Berbagai kegiatan yang dilakukan perusahaan untuk menghasilkan nilai dapat dilihat pada Gambar 3.

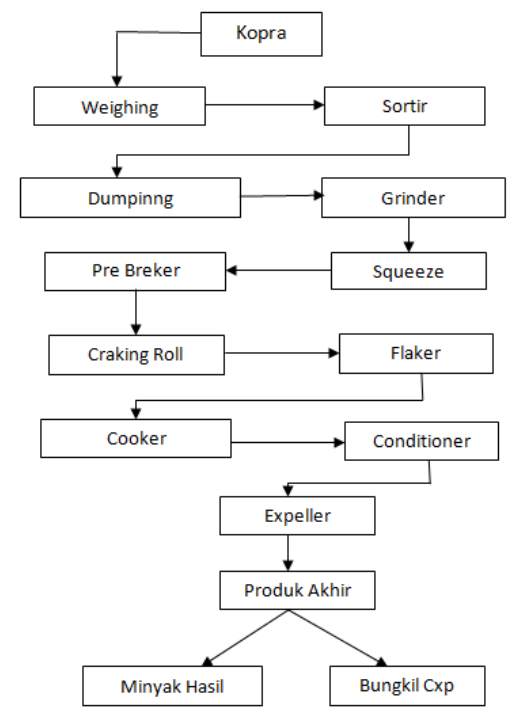

Gambar 3: Proses Utama Pengolahan Minyak Kelapa Mentah (CCO) di Tingkt Perusahaan 
Setelah bahan baku sampai di lokasi pabrik truk beserta isisnya akan berhenti pada jalur timbangan untuk ditimbang (Weighing) secara otomatis yang akan menunjukan berat dan akan tercetak pada formulir.

Setelah proses penimbangan, kopra akan dibawah menuju copra dumping dimana kopra dumping adalah tempat penampungan semua bahan baku/material (kopra) yang dibutuhkan oleh perusahaan kemudian akan diproduksi.

Kopra yang masuk dalam pre breker akan dicincang menjadi halus kira-kira sampai $45 \%$ $50 \%$. Ada dua unit pre breker tidak dioperasikan sekaligus melainkan hanya mengoperasikan salah satu unit pre breker sedangkan yang satunya lagi stan by. Grinder memiliki 3 unit masing-masing dilengkapi dengan sebuah motor penggerak dengan daya sebesar $60 \mathrm{HP}$ serta coupling dan rantai sebagai penghantar putaran dan daya motor. Setelah dihancurkan kopra kemudian akan jatuh ke Drag Conveyor yang berada dibawah grinder untuk kemudian akan membawa kopra menuju ke 3 unit Cracking Roll. Kopra yang masuk pada Cracking Rollakan dihancurkan sampai mencapai 60\%-65\% dengan ukuran screen 8. Flaker adalah tahap akhir dari pengukuran material kopra sebelum kemudian dimasukan ke dalam Cooker.

Minyak hasil perasan, minyak yang sudah bersih dari bungkil akan dipompa dengan menggunakan Fit Pump keluar dari Screening Tank menuju ke oil Heater untuk dilakukan proses pemanasan sampai mencapai suhu $110^{\circ} \mathrm{C}$. Fungsinya agar minyak akan menjadi lebih encer sehingga lebih mudah tersaring saat masuk ke dalam Filler area. Bungkil hasil sisa perasan kemudian diambil sampl untuk dibawah ke laoratorium untuk diperiksa dan dilakukan pengukuran seberapa besar kadar minyak yang masih terkandung didalamnya. Hal ini dilakukan, mengingat semakin besar kadar minyak terbawa bersama-sama dengan bungkil, maka perusahaan akan mengalami kerugian dalam hal kapasitas minyak perharinya. Ukuran (RO) yang distandarkan oleh perusahaan adalah 7,5-8,6 \%. Bungkil yang keluar dari expeller masih berbentuk gumpalan-gumpalan yang berukuran sedang, jadi bungkil tersebut akan dimasukan kedalam cake breaker untuk dihancurkan sampai menjadi halus. Setelah itu, bungkil akan di hantar oleh drag conveyor menuju kedalam gudang penampungan.

\section{Alur Produk dalam Rantai Nilai}

Berdasarkan hasil penelitian, alur produk dalam rantai nilai kopra dari petani, kemudian pedagang perantara melakukan pendistribusian kepada perusahaan sebagai pengolah. Kemudian perusahaan mengolah bahan baku menjadi minyak kelapa mentah yang siap untuk diekspor. Dapat dilihat pada Gambar 4.

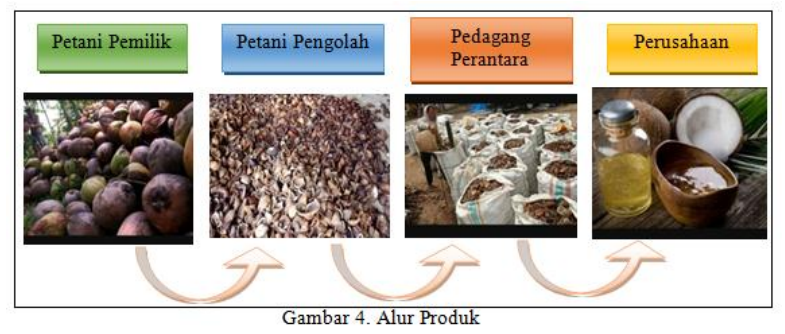

Gambar 4 menunjukkan bahwa alur produk dalam rantai nilai minyak kelapa (CCO) yang mana melibatkan para pelaku ranrai nilai mulai dari petani pemilik, petani pengolah, pedagang perantara, dan perusahaan.

\section{Biaya-biaya pada Pelaku Rantai Nilai}

Biaya tetap adalah biaya yang besarnya tidak tergantung pada jumlah produksi.Pembelian lahan, gedung, mesin, dan bunga pinjaman termasuk dalam biaya tetap. Biaya variabel adalah biaya yang besarnya tergantung pada tingkat produksi, misalnya upah tenaga kerja, biaya bahan baku.

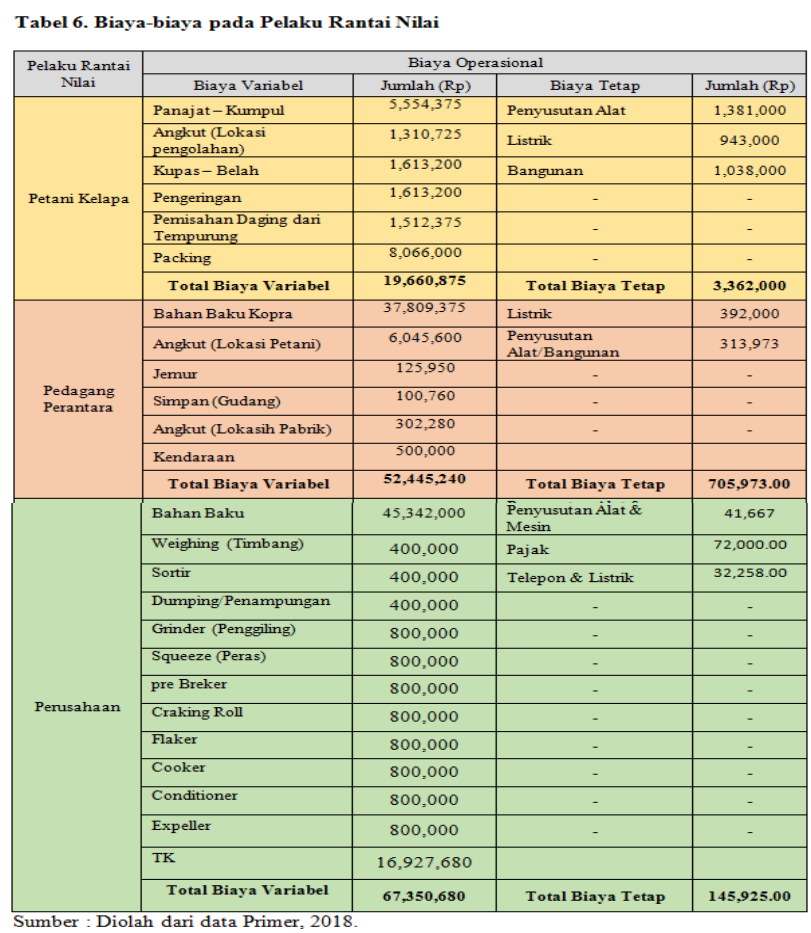




\section{Keuntungan Para Pelaku Rantai Nilai}

Keuntungan merupakan penghasilan bersih yang diterima oleh pelaku rantai nilai setelah dikurangi dengan biaya-biaya produksi. Keuntungan yang didapat disesuaikan juga dengan bahan baku atau hasil produksi suatu produk. Menurut hasil penelitian, keuntungan atau nilai yang diterima oleh para pelaku rantai nilai produk kopra dapat dilihat pada Tabel 7.

Tabel 7. Keuntungan Para Pelaku Rantai Nilai

\begin{tabular}{|c|c|c|c|}
\hline \multicolumn{3}{|c|}{ Pelaku Rantai Nilai } & Nilai (Rp) \\
\hline \multirow{3}{*}{ Petani } & Buah Kelapa & 20.165 & \multirow{3}{*}{$37,809,375$} \\
\hline & $\begin{array}{c}\text { Produksi Kopra } \\
(\mathrm{Kg})\end{array}$ & 5.041 & \\
\hline & $\begin{array}{c}\text { Harga jual } \\
(\mathrm{Rp} / \mathrm{Kg})\end{array}$ & 7,500 & \\
\hline \multirow[b]{2}{*}{ Pedagang } & Bahan Baku (Kg) & 5.038 & \multirow[b]{2}{*}{$42,832,000$} \\
\hline & $\begin{array}{c}\text { Harga jual } \\
(\mathrm{Rp} / \mathrm{Kg})\end{array}$ & 8,500 & \\
\hline \multirow{5}{*}{ Perusahaan } & Bahan Baku (Kg) & 5.034 & \multirow{5}{*}{$84,134,600$} \\
\hline & $\begin{array}{c}\text { Produksi CCO } \\
(\mathrm{Kg})\end{array}$ & 3,527 & \\
\hline & $\begin{array}{c}\text { Produksi Bungkil } \\
(\mathrm{Kg})\end{array}$ & 1,007 & \\
\hline & $\begin{array}{c}\text { Harga Jual CCO } \\
(\mathrm{Rp} / \mathrm{Kg})\end{array}$ & 23,000 & \\
\hline & $\begin{array}{c}\text { Harga Jual } \\
\text { Bungkil }(\mathrm{Rp} / \mathrm{Kg})\end{array}$ & 3,000 & \\
\hline
\end{tabular}

Tabel 7 menunjukkan banyaknya pohon yang berproduksi, berapa banyak bahan baku kelapa yang digunakan oleh petani dalam meproduksi kopra. dari Hasil produksi kopra dapat menunjukkan nilai yang diterima oleh pelaku petani dan pedagang perantara. Hasil produksi minyak kelapa mentah $(\mathrm{CCO})$ dan bungki dapat menunjukkan nilai yang diterima oleh perusahaan.

Berdasarkan hasil penelitian, kopra yang diproduksi petani sebanyak $5.041 \mathrm{~kg}$ dengan bahan baku 20.165 buah kelapa. Dengan harga jual kopra sebesar Rp.7.500/kg dan nilai yang diterima oleh petani sebesar Rp.37.809.375 untuk 1 kali produksi.

Berdasarkan hasil penelitian, pedagang perantara membeli bahan baku kopra dari petani sebanyak $5.041 \mathrm{~kg}$ kemudian menjual kepada perusahaan sebanyak $5.083 \mathrm{~kg}$ dengan harga $8.500 / \mathrm{kg}$ dan nilai yang diterima oleh pedagang sebesar Rp.42.832.000 untuk satu kali penjualan.

Berdasarkan hasil penelitian, perusahaan membeli bahan baku kopra dari pedagang sebanyak $5.083 \mathrm{~kg}$. Dari bahan baku kopra, perusahan meproduksi minyak kelapa mentah (CCO) sebanyak $3.527 \mathrm{~kg}$ dan bungkil $1.007 \mathrm{Kg}$ kemudian mengekspor $\mathrm{CCO}$ dengan harga Rp.23.000/kg dan bungkil dengan harga Rp.3.000/Kg nilai yang diterima oleh perusahaan sebesar Rp.84.134.600

\section{Skema Biaya dan Margin}

Menurut Kaplinsky dan Morris (2001) dalam ACIAR, (2012) melalui analisis margin dan laba di dalam rantai nilai, dapat dilihat siapa saja yang memperoleh manfaat dari partisipasi dalam rantai nilai dan pelaku mana yang dapat memperoleh manfaat dari dukungan atau pengorganisasian yang lebih baik. Skema biaya dan margin dapat dilihat pada Gambar 5 .

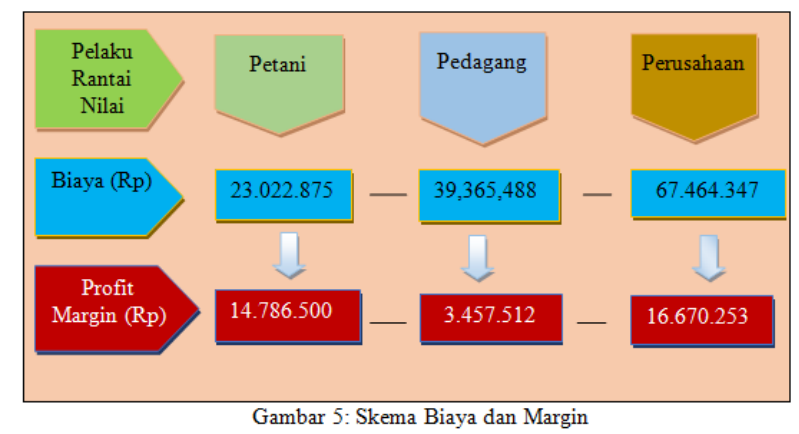

Berdasarkan hasil penelitian margin yang diperoleh petani yaitu selisi nilai yang diterima setelah dikurang biaya sebesar Rp.14.786.500 dan Margin yang diperoleh pedagang perantara yaitu selisi nilai yang diterima setelah dikurangi biaya sebesar Rp.3.457.512 sedangkan untuk persahaan margin yang diterima yaitu selisi nilai dikurangi biaya sebesar Rp.16.670.253.

Hasil penelitian menunjukkan bahwa dalam analisis rantai nilai melalui pendekatan biaya dan margin pelaku yang terlibat dalam rantai nilai kopra masing - masing memperoleh margin yang sesuai dengan usaha yang telah dilakukan.

\section{KESIMPULAN DAN SARAN}

\section{Kesimpulan}

Berdasarkan hasil penelitian dapat disimpulkan bahwa dalam analisis rantai nilai Produk minyak kelapa mentah (CCO) di Kecamatan Sinonsayang terdapat beberapa pelaku yang terlibat diantaraya adalah petani 
kopra kemudian pedagang Perantara dan PT. Cargill. Dari hasil penelitian, kopra yang diproduksi petani sebanyak $5.041 \mathrm{~kg}$ dengan bahan baku 20.165 buah kelapa. Dengan harga jual kopra sebesar Rp.7.500/kg dan nilai yang diterima oleh petani sebesar Rp.37.809.375. Pedagang membeli bahan baku kopra dari petani sebanyak $5.041 \mathrm{~kg}$ kemudian menjual kepada perusahaan sebanyak $5.083 \mathrm{~kg}$ dengan harga $8.500 / \mathrm{kg}$ dan nilai yang diterima oleh pedagang sebesar Rp.42.832.000 Perusahaan membeli bahan baku kopra dari pedagang sebanyak $5.083 \mathrm{~kg}$. Dari bahan baku kopra, perusahan meproduksi minyak kelapa mentah (CCO) sebanyak $3.527 \mathrm{~kg}$ dan bungkil 1.007 $\mathrm{Kg}$ kemudian mengekspor $\mathrm{CCO}$ dengan harga Rp.23.000/kg dan bungkil dengan harga $\mathrm{Rp} .3 .000 / \mathrm{Kg}$ nilai yang diterima oleh perusahaan sebesar Rp.84.134.600. Masingmasing pelaku rantai nilai memperoleh margin yang sesuai dengan usaha yang dilakukan.

\section{Saran}

Berdasarkan kesimpulan penelitian, maka penulis merekomendasikan saran untuk PT. Cargill, pedagang perantara dan paling yang paling penting adalah petani kopra agar lebih memperhatikan, pertumbuhan tanaman kelapa, ketersediaan kopra, dan mutu dari bahan baku untuk proses selanjutnya.

\section{DAFTAR PUSTAKA}

ACIAR, 2012. Membuat Rantai Nilai Lebih Berpihak pada Kaum Miskin. ACIAR Monograph No. 148. Australian Centre for InternationalAgricultural Research: Canberra. 146 halaman.

Badan Pusat Statistik 2016. Kabupaten Minahasa Selatan dalam angka. BPS Kabupaten Minahasa Selatan.

Yokebet B. S. N. 2015. Analisis Rantai Nilai Komoditi Gula Kelapa Di Kecamatan Cilongok Kabupaten Banyumas.Skripsi. Fakultas Ekonomika Dan Bisnis. Universitas Diponegoro. Semarang. 